Article

\title{
The Role Innovative Housing Models Play in the Struggle against Social Exclusion in Cities: The Brisbane Common Ground Model
}

\author{
Petra Perolini \\ Design Department, Queensland College of Art, Griffith University, South Bank, Qld 4103, Australia; \\ E-Mail: p.perolini@griffith.edu.au
}

Submitted: 15 May 2014 | In Revised Form: 21 January 2015 | Accepted: 27 January 2015 |

Published: 9 April 2015

\begin{abstract}
The history of housing in Australia is a textbook example of socio-spatial exclusion as described, defined and analysed by commentators from Mumford to Lefebvre. It has been exacerbated by a culture of home ownership that has led to an affordability crisis. An examination of the history reveals that the problems are structural and must be approached not as a practical solution to the public provision of housing, but as a reshaping of lives, a reconnection to community, and as an ethical and equitable "right to the city". This "Right to the City" has underpinned the Common Ground approach, emerging in a range of cities and adopted in South Brisbane, Queensland Australia. This paper examines the Common Ground approach and the impacts on its residents and in the community with a view to exploring further developments in this direction. A clear understanding of these lessons underpins, and should inform, a new approach to reconnecting the displaced and to developing solutions that not only enhance their lives but also the community at large.
\end{abstract}

\section{Keywords}

Australian housing; Common Ground; Great Australian Dream; public housing; social exclusion; socio-spatial divisions; urban disadvantage; urban marginalisation

\section{Issue}

This article is part of the special issue "Housing and Space: Toward Socio-Spatial Inclusion", edited by Dr. Dallas Rogers (University of Western Sydney, Australia), Dr. Rae Dufty-Jones (University of Western Sydney, Australia) and Dr. Wendy Steele (RMIT University, Australia).

(C) 2015 by the author; licensee Cogitatio (Lisbon, Portugal). This article is licensed under a Creative Commons Attribution 4.0 International License (CC BY).

\section{Introduction}

Today's cities are faced with the challenges of rapid population growth, urban sprawl, housing shortages, urban decay, increasing social segregation and the geographical, climatic, political and economic displacement of the disadvantaged. Common Ground attempts to overcome this historical trend through an inclusive approach.

Repeated cycles of government policy designed to address the problems of adequately housing the disadvantaged have only created new nightmares of exclusion. Outer suburban ghettoes have replaced inner city slums; satellite cities have failed to provide a solution and consumed millions in attempts to retrofit infra- structure and rectify poor planning; mixed land-use projects, designed to provide affordable housing, have become trendy and expensive: all these approaches failed to provide housing for homeless and displaced people let alone the more general challenge of rebuilding community.

The greater the social cohesion of a community, the more resilient it becomes (Pelling, 2003). The practical, rapid response of constructing housing in low-cost areas with the addition of a minimum of support services therefore exacerbates rather than alleviates the problem. Thus, design approaches to housing the homeless, displaced and low-income earners must expand their horizon and address the challenge as one of reshaping lives, reconnecting community, and providing an ethi- 
cal and equitable "right to the city".

In the last decade academics and social movements have framed this social injustice to housing struggles in terms of "The right to the city". "The right to the city cannot be conceived of as a simple visiting right or as a return to traditional cities. It can only be formulated as a transformed and renewed right to urban life" (Lefebvre, Kofman, \& Lebas, 1996, p. 158).

The challenge then is to explore possibilities outside of pragmatic solutions and encourage a new urban, one that aims to deliver reconnected and inclusive cities that offer a renewed sense of place, purpose and future. Housing plays a central role in this social justice debate and affordable housing initiatives are becoming more important globally. Relevant responses must start with that outcome in mind and work to overcome the obstacles that resist its delivery. The Common Ground approach meets a number of these requirements.

This paper aims to contribute to the debate of urban social exclusion and offers a range of lessons and potential solutions that form an essential input into the development of future urban design approaches. The paper focuses first on a theoretical review of urban theory before examining the "right to the city" in an Australian historical context leading to a discussion of Brisbane's Common Ground. Finally, the paper argues that the dialectic between urban policies, the shapers of our urban centres and the emergence of social initiatives need to be brought into alignment with the imperative of an ever increasing divide.

\section{Developing the Urban}

To understand the challenge facing inclusive approaches to urban design such as Common Ground it is essential to understand the forces underpinning historical urban development.

City planners have long explored the balance of power in the city and the role played by capitalism in socio-spatial fragmentation. American historian, sociologist and critic Lewis Mumford contends that by the 17 th century, capitalism had changed the balance of power of the Western city.

That focus on profit moved land from a system of feudal tenure (a long-term generational lease system with reciprocal duties between landlord and tenant) into a commodity, a means of making money. The disadvantage thus fell on the poor. As rents escalated, properties simultaneously fell into disrepair; landlords made no long term obligations to tenants, overcrowding became rife and so arose the first slumhousing. On the outskirts of the city, farms coming out of tenure were divided into building lots, and by the early nineteenth century indefinite expansion became possible within a laissez faire approach to property ownership (Mumford, 1961, pp. 474-475).
From the 1960s, additional approaches to exploring urban fragmentation have drawn upon the work of Marx and Engels, where the capitalist city, in the accumulation and circulation of profit, produces class based upon social divisions (Engles, 1968). Scholars such as Henri Lefebvre, Manuel Castells and David Harvey, despite their theoretical, methodological and political differences, all share a concern to understand the ways which urban communities, under capitalism, are commodified.

In particular, modernist architectural thinking comes under intense criticism from Lefebvre, as working from an externalised perspective with little reference to lived experience (habiting - not simply inhabiting) (Lefebvre et al., 1996, pp. 152-154). Lefebvre singles out Le Corbusier, whom he describes as, "a good architect but a catastrophic urbanist, who prevented us from thinking about the city as a place where different groups can meet, where they may be in conflict but also form alliances, and where they participate in a collective oeuvre" (Lefebvre et al., 1996, p. 207).

David Harvey is equally critical of the roles of architecture and urbanism in structuring the urban, blaming investment and financial reasoning, built upon a continuous cycle of long waves of investment: over accumulation, devaluation, loss of exchange value, buying at bargain prices and back to investment again (Harvey, 2002). Further, Neil Brenner expands upon Lefebvre's theories of urbanization as an increasingly global phenomenon, no longer relating only to industrialized towns and cities, but as the "stretching of an 'urban fabric', composed of diverse types of investment patterns, settlements spaces, land use matrices, and infrastructural networks, across the entire world economy" (Brenner, 2012, p. 21).

The Common Ground approach attempts to leapfrog these limitations by directly addressing the issues of integration and inclusion rather than focusing on structure and infrastructure.

\section{Spatial Exclusion in Australia}

The Common Ground experiment in Australia attempts to address the challenges facing the homeless and disadvantaged in a rich country with a high proportion of home ownership and large amounts of open space leading to sprawling, low density cities.

Although "the bush" has defined Australia's historic identity, today's population is heavily urbanised, with approximately $88 \%$ of Australians now living in metropolitan areas. One of the wealthiest nations globally, Australia is no stranger to problems of poverty and exclusion. Disadvantage can be found in almost every city and larger regional centre (Communities, 2011).

From the late 19th century, "progressive" planning movements have asserted the value of home ownership and a suburban "Great Australian Dream" as a 
method of remedying social issues of densely populated areas. Following US and British trends, high-density housing was stigmatised as "slum" housing. Social reformers of the "Garden City" and "City Beautiful" movements were concerned with promoting health and vitality in urban living (Butler, 2012).

In 1909 a Royal Commission for the improvement of Sydney recommended the creation of garden suburbs for the working classes, resulting in the country's first regional plan (Cox, Graus, \& Meyer, 2011). Daceyville Garden Suburb in Sydney was the first and possibly most influential of these Garden Suburbs. It aimed to demonstrate a better standard of living with lower density, wide-open curving streets, no front fences, quarter acre blocks, street planting and public open spaces (Cox et al., 2011).

Despite its initial positive reception, low-density living took on a new momentum following World War II, when all cities expanded dramatically. The new proposals were translated into local council by-laws with minimum allotment sizes and design standards, inclusion of public parks and spaces, and covenants. Developers built new suburbs and satellite towns of private lower-income and public housing to meet the bare minimum of the social tolerance threshold (Butler, 2012). According to Butler,

While the development of the suburbs can be attributed partly to the growth of industrialisation, it cannot be separated from the deeply anti-urban ideology that was prominent among the early planning reform movement and helped to normalise the "quarter-acre block" as a spatial form maximising private space to the detriment of public space. (Butler, 2012, p. 117).

In 1948 an Abercrombie-inspired satellite town model was proposed for Sydney's Country of Cumberland Plan, with a plan of slum clearance in suburbs such as Surry Hills, Redfern and Balmain to be replaced by Corbusier-style high rises, a greenbelt at a $20 \mathrm{~km}$ distance from the $C B D$, and beyond that satellite towns such as Campbelltown and Penrith. Although developed as a "balance" to counteract the growth of the city, the result is a bimodal population split between high income commuters on the one hand and socially excluded residents on the other.

As the demand for affordable housing intensified, the sites of Green Valley and Mt Druitt were chosen as low cost public-housing estates based upon the Radburn, New Jersey open-public-space design of Clarence Stein. Unlike the British models, these suburbs failed to integrate housing with employment. That was exacerbated by the policy that residents were required to be low-income earners and eligible for public housing. Travel distances to work, reliance on a fast transport system or private vehicle, low employment rates and bad press soon led inevitably to social stigmatisation (Cox et al., 2011).

By 1968, the greenbelt had been abandoned due to rapid population growth. The Sydney Regional Outline Plan developed, based upon a European linear model of railway corridors with each corridor to be made up of a collection of new towns with primarily detached dwellings (Cox et al., 2011). Satellite towns such as Campbelltown, $50 \mathrm{~km}$ south of Sydney were reinvented with a town centre, employment prospects, university, hospital, public transport and a mix of private and public housing. However, the growth of the affordable outer suburbs soon outstripped employment, transportation and infrastructure, all of which remain a challenge in these areas (Cox et al., 2011).

In search of an answer, brownfield developments such as South Bank in Brisbane, Docklands in Melbourne and Pyrmont in Sydney became popular in an attempt to promote inner-city dwelling and reduce urban sprawl in the 1980s and 1990s. Again they were derived from international models such as the Docklands development in London based upon a high density "New Urbanism" (Cox et al., 2011). Developments with high-end apartments, restaurants, bars and entertainment located in inner-city prime locations proved extremely popular with an inner-city, gentrified middle-class; the disadvantaged populations, historically concentrated in inner-city areas, were pushed out to peripheral suburbs. Today the post-war central suburbs are being rezoned and redeveloped with mid-level mixed use development along public transport routes, once again escalating housing prices and relegating the less fortunate to the peripheries.

The repeated failure of these different models of urban development to address the structural problem of unequal "rights to the city" indicates that the core approach of providing additional infrastructure is insufficient.

\section{The Ownership Axis}

One challenge faced by any social housing approach in Australia is the intense desire for and encouragement of home ownership. Over the century long history of the nation, this has led to public money being injected into incentives and support for homeownership and the cultural ideology of the "Great Australian Dream" (Jacobs, Atkinson, Colic Peisker, Berry, \& Dalton, 2010).

In the early decades of the 20th century, Australian governments promoted home ownership through state banks and war service home loans. In the mid-1930s, the Australian labour movement ensured that wage levels were kept above a minimum and marginal tax was kept low, further enabling and encouraging home ownership (Jacobs et al., 2010).

From the 1960s to 1970s, the policy appetite for public housing returned and high-rise, public-housing 
estates replaced inner-city terrace housing (Jacobs et al., 2010). At the time of construction, these projects were seen as a cutting-edge solution to social issues (March 2003). However these housing models were illfated. The estates were soon criticised by residents and the public for unattractiveness and lack of social planning (Atlas \& Dreier, 1994). They soon became associated with crime and low morale.

By 1978 , the Commonwealth had greatly reduced the amount of funding for building and maintaining public housing (Groenhart, 2012).

"The result of dwindling funds was a shift in the role of public housing, from a mainstream option to marginal sector with a highly disadvantaged tenant base. By 2006 , around $90 \%$ of tenants were either on welfare benefits or experiencing some other form of social deprivation" (Groenhart, 2012). Governments have thus turned to the private market to "fund the renewal of their housing estates through policies branded as 'social-mix'”' (Jacobs et al., 2010, pp. 20-23).

This ideology of home ownership has created a unique population in Australian cities: the "renting poor". Given that Australia's public-housing sector is very small $(5 \%)$ compared with its counterparts in other western cities, the private rental remains a robust part of the Australian housing system. As a market liberal society, Australia places considerable faith in the market and is highly protective of individual property rights and thus of home ownership (Burke, 1999). The result has been an investment-based approach to managing rental properties that disadvantages the tenant in ways similar to the four centuries old patterns described by Mumford.

\section{The Right to the City}

There are many more poor and disadvantaged households in the private rental sector than in social housing (Hulse \& Burke, 2000). Studies show that anti-social behaviour, an increase in crime; social stigma, poor education and general dysfunction are all symptomatic of life in social housing (Morris, Jamieson, \& Patulny, 2012). Living in marginalised clusters can have the following long-term consequences: a gradual loss of confidence in the "system", long-term unemployment, limited or no participation in active citizenship, the prompting of a sense of failure, rejection and shame is often passed down through the generations (Hulse \& Burke, 2000).

The spatial distribution of the socially disadvantaged is evident in every Australian city. Clusters of deprived people and poor neighbourhoods are concentrated in fringe suburban areas.... There is evidence that the disadvantaged living conditions are being passed from one generation to the next (Pawson \& Herath, 2013).

The answer, then, comes from some mechanism that deals with the concept of "social mix". So far, planning schemes, housing policies and other strategic approaches have failed to stop the growing concentration of disadvantage in Australia's suburbs. Affordable housing is at the centre of the debate. Recognising the urgency, in 2008 the Australian Government released a White Paper on Homelessness, outlining policies on addressing disadvantaged citizens. A year later, the $\mathrm{Na}$ tional Affordable Housing Agreement (NAHA) followed, complemented later by the National Partnership Agreements on Homelessness and Social Housing. These national agreements underpin the Queensland Housing 2020 Strategy. Launched in 2013, this strategy addresses Queensland's social housing system and promises to bring it in line with current demands (Department of Housing and Public Works, 2013) Consequently, Common Ground Brisbane secured part funding from the National Partnership Agreement on Homelessness. The Queensland Government through the National Building Economic Stimulus Plan provided the other funding. The building is pioneering affordable housing and social inclusion in Brisbane and is adding to the discussion on social mix as a case study.

\section{The Common Ground as a Counter-Point}

Common Ground, established in 2008 , is Queensland's first specialist supportive housing tenancy and property management organisation. The organisation focuses on providing quality tenant outcomes for people who have experienced chronic homelessness or earn a low income. It attempts to tackle the problem of exclusion in a number of ways:

1. offer permanent, safe and affordable housing to the disadvantaged in the community

2. provide a vibrant community life within the building itself

3. extend that community live by engaging with and contributing to the surrounding neighbourhood

4. bring the surrounding community into the project through leasing commercial and community spaces

In short, the project attempts to shift the emphasis from the value of the property or infrastructure to the value of the service by valuing the benefits of integration above the cost of the project.

This paper examines the degree of success in that endeavour and the lessons that have been learned. The methodology employed is semi-structured in-depth interviews, and is discussed in detail below. The reality is that the project is new, a post-occupancy review has not been completed, and there is little empirical evidence available to date. Three interviews were conducted as part of a larger project that presented visual and auditory elements in the form of an exhibition in September 2014: 
- Interview 1: Karyn Walsh, Coordinator Micah projects, 20 August 2014.

- Interview 2: Common Ground resident, male in his 50s (wanted to remain anonymous), 5 August 2014.

- Interview 3: Lesley Rankin, former hospitality employee near Hope Street South Brisbane, 5 August 2014.

\subsection{Physical Infrastructure}

Common Ground, in a partnership with Micah Projects, a community-based not-for-profit with a commitment to social justice, and a number of other key partners delivered a building on 15 Hope Street, South Brisbane, which houses 146 people in single units or studios. Fifty per cent of tenants were chronic homeless with the other 50 per cent on low income (Department of Housing and Public Works, 2013). The project offers permanent, safe and affordable housing to the community. Furthermore, the concept provides a vibrant community life both within the building itself, and in engaging with and contributing to the surrounding neighbourhood (Australian Common Ground Alliance, 2013).

The building itself is located on prime inner-city land, across the river from the CBD, adjacent to the city's arts and cultural precincts at South Bank, with direct access to public transport. The project is unusual in that it results from an innovative partnership between federal and state governments, business and community. Funding for the building was provided by the Australian Government and Queensland Government, under the Nation Building Economic Stimulus Program and the COAG National Partnership Agreement on Homelessness. That Stimulus Program was a high level policy decision to invest billions in infrastructure as a response to the global financial crisis. As such it was a unique opportunity to create a housing project outside the accepted norms of urban planning and design.

Construction company Grocon offered its services for the project on a not-for-profit basis, as did many other participating businesses. Nettleton Tribe (architects, interior designers, master planning and urban design) were awarded the tender to design and document the project. Combining 146 single bedroom and studio residential units, breezeways, common spaces, art and computer rooms, rentable conference rooms and retail tenancies, the top floor also houses a fully commercial training kitchen with an extensive rooftop edible garden, and relaxation areas. The building's foyer is complete with a fully-staffed concierge desk, lounge areas and a grand piano for use by the tenants.

In terms of ongoing support, Common Ground Queensland Ltd provide the ongoing tenancy management for the project, whilst Micah Projects Inc. provides 24 hour on-site support services for tenants (including encouraging independent living, vocational training, employment and education and access to health professionals). Both of these community organisations, as members of the Australian Common Ground Alliance, were strongly involved in the inception, development and implementation of the project (Micah Projects, 2013). Rent is based upon individual tenant income and is charged as a percentage, which accommodates flexibility in cases of loss of income or reduced working hours.

\subsection{Measures of success}

The building, on a site that is historically been associated with Brisbane's homeless is surrounded by highpriced inner-city living. The philosophy of creating a social mix, rather than pushing the marginalized and those who had previously been sleeping rough out of sight to the suburbs has met some challenges. Attracting health care and community care organisations to the lower floor retail spaces, and utilising the building as a community asset has been slower than hoped. However, there has been a gradual increase in bookings of the rentable conference spaces and commercial kitchen/rooftop asset, which, Micah is confident, will increase in the future ( $\mathrm{K}$. Walsh, personal communication, August 20, 2014). By making public spaces available for use by the larger community and business sector, it is hoped that the socio-spatial divide and any remaining stigmatisation associated with the buildings tenants will diminish.

All interviewees shared a concern for social exclusion. In fact there was a strong perception that social exclusion is growing worse in Brisbane, suggested by the increasing demand for housing in Common Ground. All interviewees stressed the importance of building a strong relationship between Common Ground tenants and the neighbouring community to alleviate exclusion and ease the transition from years of isolation and dysfunction to a future of purpose and hope. In line with the literature review, all interviewees referred to the enormous challenges the project had to overcome by establishing social housing in an area of Brisbane where real estate prices are high. One interviewee mentioned that on several he saw Common Ground tenants struggling to justify to other residents in the area why they can afford to live in an area where the rents are above the average. The same interviewee also observed that it had initially been difficult to change the perception that the public and community had of the Common Ground tenants. He noted that there is now a shift toward valuing diversity and community inclusion.

\subsection{Culture Change, Diversity and Positive Discrimination}

All interviewees agreed that a complete culture change 
is needed to transform the housing situation in Brisbane. One expected the situation to get worse as the aging of the population increased the rates of homelessness and poverty. Another commented that while projects like Common Ground have improved perceptions of the marginalised and disadvantaged, such projects only treat the symptoms but not the cause. In his view, many of the symptoms of social disconnection can and should have been remedied much earlier. However, in his opinion, the present social, economic and political structures preclude early intervention.

Fixed social norms were an area of concern for all interviewees, which they thought was one of the main enablers of stigmatisation. A lack of public understanding of the effects of homelessness, disadvantage, disconnectedness and stigmatisation explained why some of the tenants of Common Ground felt different and excluded. Everyone insisted that problems of acceptance of the new neighbours had been anticipated but that the advantages of staying local and being close to support services outweighed the challenges foreseen. One interviewee described the current tenants of Common Ground as interesting people who livened up the area. Many of them were artists or musicians and the local hospitality businesses enjoyed their patronage.

It was generally agreed that the South Brisbane community in the vicinity of Hope Street supported Common Ground but there were always going to be opponents. Karyn Walsh commented:

"This was always going to be the case. You can educate people and you can hold many community meetings but there are always people who lack empathy and who can't envisage the positive contribution the new tenants could make. The challenge, I think, is getting people on side in an inner city location where prices are high. What are the implications of this for the rest of the community? Is it fair that some people pay 800 dollars a week and others only pay 120 dollars for the same thing? These were issues floating around and it created quite some debate. But we really wanted and pushed for this location because we felt that people had lived in the area for a long time and had already faced being displaced from the many hundreds of units being built in this area. Why not include some that were affordable and cater for people who had actually lived in the area so they could in fact stay in the area". (K. Walsh, personal communication, August 20, 2014)

\subsection{The Intended Use of the Facility}

One interviewee commented that Common Ground was designed to be a community asset. There are many rentable spaces within the facility, including confer- ence and function rooms that the community is now starting to use. Although this was slow to develop, the bookings are steadily increasing.

The concept had derived from research and case studies of similar projects, which saw the benefit in bringing the community into the building. The benefits were twofold. They allow for the establishment of mixed communities to establish a balanced neighbourhood, where both sides can benefit from each other. The second was to alleviate some of the stigmatisation, particularly at the beginning of the project. This was achieved by showcasing the excellent facilities the building offers, creating the possibility for tenants to mingle and play the grand piano, to enjoy the first class facilities, the security, the tastefully designed spaces and the amazing vistas of river and city.

One interviewee stated that the mixing interrupts patterns of social segregation. Micah Projects agrees that mixing prevails undermines anti-social conduct and dependency. This thinking is in line with the research and underpins the view that new housing developments should have a diversity of affordable homes.

All three interviewees praised the amenities facilities the building offers to its tenants (cooking facilities, computer rooms, shared spaces).

"By allowing tenants to gain some skills in the safety of their own homes, provides them with the necessary skills to confront the 'outside' world, a place they have been cut off from for a long time". Two interviewees mentioned a lack of confidence in their ability to find employment. "When it comes to applying for jobs, especially the long-time unemployed tenants worry about their ability to fit in and to sustain a job". One interviewee made reference to the empty commercial tenancies on the ground level. Originally earmarked to house a medical centre, the building has failed to secure a tenant in its first two years of operation. "If I was going to do this again, I would invest in the whole concept. Funding needs to be put into getting the commercial tenancies up and running rather than leaving this for a later stage" (K. Walsh, personal communication, August 20, 2014).

\subsection{Monitoring the success}

The building is in its second year of operation and a post-occupancy evaluation has yet to be conducted by the State Government. Two interviewees said they found Common Ground a great initiative for social inclusion. However there was some criticism about its future success and concern was expressed about the fairness of the selection of tenants. One interviewee was concerned that the waiting lists to get a place in Common Ground are long and disappointment was expressed at the selection process of choosing tenants. 
"Some of the real hardship cases seem to fall off the radar. Maybe this is because they disappear and are just not around when the waiting lists are updated or maybe they are not considered 'suitable'" (Interviewee 2, personal communication, August 5,2014$)$.

One person said that the selection process is very complex and might appear unfair to people who don't have the full picture. She agreed that it is disappointing that the organisation can't offer more places, as the aim is to make the living conditions better for all their clients.

"Common Ground was just one initiative and many more need [to be established] to move forward the agenda of closing in on social exclusion" (K. Walsh, personal communication, August 20, 2014).

One interviewee commented that while mixed neighbourhoods are nice to work in and live in, their "neighbourhood effects" don't do much to help the poor escape from poverty. A second interviewee agreed that simply "allowing" the poor to mix with the affluent does not necessarily generate social and economic equality.

"We might be accepted but we still don't get the same chances. We look different, we speak different, and we are different. Just because we live next to them does not change the fact that we are different. I like living here, it is a step towards becoming independent and able to live my life again and I was one of them outside many years ago, most of us were. However, it's like living in an area with an engineered social character. But living here also means that things are more expensive than in outer poorer suburbs" (Interviewee 2, personal communication, August 5, 2014).

While the real success can't be determined until some formal evaluation has been completed, all interviewees agreed that the architects, planners, designers and others had created a building which suits the character of the site and its tenants. Although Common Ground is a success from a design perspective, one interviewee thought that there was no need to replicate it.

"Any future similar buildings need to be designed to be site specific. What worked here on Hope Street might not work somewhere else. I believe the design team did an outstanding job in working with all the stakeholders in creating the vision for a building that became home for people who have been socially excluded for many years or who have been living in chronic poverty and poor living standards" (K. Walsh, personal communication, August 20, 2014).

\section{Reaping the Harvest from the Common Ground}

In summary, socio-spatial exclusion is a characteristic of urban development driven by the commodification of housing as a facet of the property market. The Common Ground project offers an unusual opportunity to examine alternative approaches and solutions that reverse this trend.

Several factors have contributed to the fragmented urban landscape in Australia, creating pockets of disadvantaged neighbourhoods. A particular feature of the Australian situation is an idealisation of homeownership, which has created a gap between poor and rich, perpetuating a housing situation based on socioeconomic classification.

Against this backdrop the paper examines Lefebvre's "right to the city" which describes the development of the "capitalist city" and its negative effects for its inhabitants and the struggle for affordable spaces in all major Australian cities. High rent, a weak social system and a lack of public housing stock have forced low-income individuals and families to neglected neighbourhoods in the outer suburbs. A lack of social mix has meant that clusters of marginalised groups form large neighbourhoods of disadvantage, suffering from stigmatisation and social exclusion. This undermining of the social cohesion of cities creates longterm problems for residents and demands action on multiple levels.

In an attempt to reverse the development of urban exclusion, some cities have started to reclaim the right to influence urban life, driven either by emerging government initiatives or by the excluded, marginalized or discriminated communities themselves. This paper focuses on one such approach to urban regenerationrenewal and the redevelopment of the social and built environment.

Common Ground is a global movement that has started to make a positive impact on our socio-spatial disadvantaged cities. Brisbane's Common Ground project has emerged as the unusual combination of a government looking to invest and a community ready to develop a creative response to these problems. A network of commercial organisations has participated in designing, developing and testing a model for future development.

Among the lessons learned are that the community in general and the commercial sector in particular must be engaged early and thoroughly to prevent the exclusion and isolation from continuing, just on a reduced scale. Design professionals, policy makers and community need to re-think the delivery of solutions for the disadvantaged as part of the delivery of services for the whole community. This is a major modification of current approaches.

Further, the support programs for education, employment and health must be integrated with the de- 
sign, development and implementation. They must also be implemented across the broader community to ensure that the social-mix is vibrant and engaged rather than post-hoc, ad-hoc and difficult.

A significant part of the challenge is that people's perceptions of community ownership of and engagement with assets and services such as those included in South Brisbane's Common Ground run counter to the capitalist notion of the urban, of property and of service delivery.

Design professionals, policy makers and community need to re-think praxis, encourage post-capitalist cities and create new forms of engaged life throughout the city. The use of planning and architecture for marginalisation and socio-spatial segregation must be reappropriated. These tools should be used not to segregate people but to construct new knowledge, new urban visions, social inclusiveness and commonality in difference.

\section{Research Methodology}

Three semi-structured in-depth interviews were conducted for this study. The study's research objective and the characteristics of the study population and the time constraint determined the number and nature of the participants.

The objective of the study: space is being understood as a social product (Henri Lefebvre). How has the planning of Australian cities contributed to a class and cultural division leading to concentrations of disadvantage? Can social initiatives such as Common Ground offer some answers and initiate change?

- Interview 1: Karyn Walsh, Coordinator Micah projects, 20 August 2014.

- Interview 2: Common Ground resident, male in his 50 s (wanted to remain anonymous), $5 \mathrm{Au}$ gust 2014.

- Interview 3: Lesley Rankin, former hospitality employee near Hope Street South Brisbane, 5 August 2014.

Interviews are used to obtain data from individuals about themselves, their involvement with Common Ground, the implementation, progress, and outcomes the project, and any future plans for similar projects. Personal interviews are widely accepted for conducting basic social science research (Seidman, 2013). For these reasons, the researcher chose a descriptive research methodology and designed an interview to assess the initial success of Common Ground as a model of social inclusiveness in an established, affluent, innerurban area. In light of time constraints and the relative weight of the expert interviews in relation to the literature review, three interviews, between 45 and 60 minutes each, has been deemed appropriate. The interviews consisted of three sections:
1. What do you see as some of the barriers to having a Common Ground Building in the midst of a thriving commercial and residential sector of South Brisbane?

2. Can you describe any examples of initiatives that are breaking down the barriers of social exclusion?

3. Do you have any advice on how to do things differently for any similar future projects?

The data collection, although narrow, will be part of the author's ongoing research into urban social inclusiveness.

\subsection{Data Evaluation}

The steps of the interview procedure are listed and described below:

1. Transcribing Interviews: all relevant parts of the recorded interview data were transcribed from audio to text format.

2. Reading and analysing the data in order to arrive at a general sense of the discussion and meaning of the data. This process identified relevant themes and categories.

3. Sorting the common themes and organising the material into chapters of information that give insight into the emerging levels of reflections.

\section{Acknowledgements}

I thank my department colleague Naomi Hay for her insight and expertise that greatly assisted the research.

\section{Conflict of Interests}

The author declares no conflict of interests.

\section{References}

Atlas, J., \& Dreier, P. (1994). What went wrong? National Housing Institute, September/October (74), Retrieved from http://www.nhi.org/online/issues/ 77/pubhsg.html

Australian Common Ground Alliance. (2013, August 10). Queensland. Australian Common Ground Alliance. Retrieved from http://www.commonground australia.org.au/index.php/state/queensland.html

Brenner, N. (2012). What is critical urban theory? In N. Brenner, P. Marcuse, \& M. Mayer, Cities for people, not for profit: Critical urban theory and the right to the city (pp. 11-23). New York: Routledge.

Burke, T. (1999). Private rental in Australia. Swinburne Institute for Social Research, 1-20.Retrived from http://www.sisr.net/publications/99burke.pdf

Butler, C. (2012). Henri Lefebvre: Spatial politics, every- 
day life and the right to the city. Milton Park, Abingdon, Oxon, New York: Routledge.

Communities, A. D. (2011). Australia state of the environment: An independent report to the Australian Government Minister for Sustainability, Environment, Water, Population and Communities. Canberra: Department of Sustainability, Environment, Water, Population and Communities.

Cox, P., Graus, P., \& Meyer, B. (2011). Home: Evolution of the Australian dream. Edgecliff: Jane Curry Publishing.

Engles, F. (1968). The condition of the working class in England. Stanford: Stanford University Press.

Groenhart, L. (2012, September 28). Growing up poor in Australia: What has happened to public housing? The Conversation. Retrieved from http://the conversation.com/growing-up-poor-in-australiawhat-has-happened-to-public-housing-9853

Harvey, D. (2002). The urban process under capitalism: A framework for analysis. In D. Harvey \& B. Watson (Eds.), The Blackwell city reader. Malden: Blackwell Publishers.

Hulse, K., \& Burke, T. (2000). Social exclusion and the private rental sector: The experiences of three market liberal countries. International Research Conference: Housing in the 21st Century. Melbourne: Swinburne University of Technology.

Jacobs, K., Atkinson, R., Colic Peisker, V., Berry, M., \& Dalton, T. (2010). What future for public housing? A critical analysis. Melbourne: Australian Housing and Urban Reseach Institute.
Lefebvre, H., Kofman, E., \& Lebas, E. (1996). Writings on cities. Oxford: Blackwell.

Morris, A., Jamieson, M., \& Patulny, R. (2012). Is social mixing of tenures a solution for public housing estates? Evidence Base, 1, 1-21.

Mumford, L. (1961). The city in history: Its origins, its transformation, and its prospects. New York: Harcourt, Brace \& World.

Pawson, H., \& Herath, S. (2013). Developing a typology of socio-spatial disadvantage in Australia. In K. Ruming, B. Randolph, \& N. Gurran (Eds.), State of Australian Cities National Conference (pp. 1-19). Sydney: State of Australian Cities Research Network.

Pelling, M. (2003). The vulnerability of cities: Natural disasters and social resilience. London: Earthscan Publications.

Micah Projects. (2013, August 10). Brisbane Common Ground. Micah Projects. From: http://www.micah projects.org.au/community/brisbane-commonground

Department of Housing and Public Works. (2013, August 4). Queensland Government Department of Housing and Publics Works Housing Services. Retrieved from www.communities.qld.gov.au/community-and homelessness-programs/community-housing/newson-brisbane-common-ground

Seidman, I. (2013). Interviewing as qualitative research: A guide for researchers in education and social sciences. New York: Teachers College Press.

\section{About the Author}

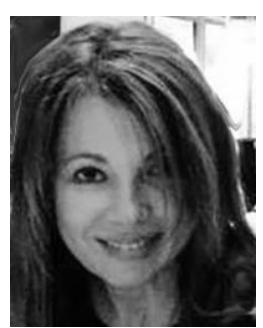

Petra Perolini

Petra is a lecturer in Interior Design and a studio course convenor at the Queensland College of Art, Griffith University. Petra has a Bachelor Degree in Interior Architecture from Switzerland, and a Bachelor Degree in Visual Arts (Interior Design) from the Queensland College of Art; she also has a Masters Degree of Urban and Regional Planning from the University of Queensland. Her research focuses on design pedagogy and new practice, encompassing interdisciplinary design to push design thinking beyond current practice. 